\title{
The effect of power system reliability problems on crucial business decisions and strategies
}

\author{
Harjit Singh Mangat $^{a^{*}}$ and Harpuneet Singh ${ }^{\mathrm{b}}$
}

${ }^{a}$ PhD Research Scholar, Department of Mechanical Engineering, I.K. Gujral Punjab Technical University, Kapurthala, Punjab, India ${ }^{b}$ Assistant Professor, Department of Production Engineering, Guru Nanak Dev Engineering College, Ludhiana, Punjab, India

\section{CH R O N I C L E}

\section{Article history:}

Received: September 19, 2018

Received in revised format: Sep-

tember 29, 2018

Accepted: October 10, 2018

Available online:

October 10,2018

Keywords:

System reliability issues

Power outages

Textile industries

Future plans

Non-parametric tests

Mitigation

\section{A B S T R A C T}

The purpose of this research was to recognize the influence of electricity reliability problems such as unplanned and planned outages, and load shedding on the future plans of the textile industries of Punjab (India). An opinion on the mitigation measures to diminish the impact of power outages was also obtained. The results presented here were got using the seven-point Likert item scale from the 148 respondents which were the part of a randomly selected sample of 400 textile industries from a total population of 1163 registered textile industries covering specifically the high concentration districts throughout the Punjab. Both formal and informal interview methods including dropping the questionnaire schedules at the industrial premises were employed to record the responses. A syntax for Krippendorff's Alpha was used in SPSS to estimate the inter-reliability of the different sections. A non-parametric Mann-Whitney U and Friedman Q with post hoc tests were applied using SPSS for independent samples and related sample designs, respectively, in order to know the statistical significant differences among the variables and the pairs. Respondents were found highly concerned towards the power system reliability issues than the quality issues. The effect of reliability issues on the micro scale industries were found higher than the small scale industries. Based on the one hour outage duration, unplanned power outage-1 hour scenario and dangerous advance warning, planned power outage, were found highly disruptive. The growth or expansion of existing unit, like to go for costly alternative energy sources, procurement of bank loans and moving industries to other state with good energy facilities, were the four key future plans and strategies that were found highly important to the textile industries. Majority of the industries believed that almost all the future plans and decisions were dominantly impacted by the unplanned outages followed by the load shedding and planned outages. In order to diminish the impact of power outages, improved system protection and improved local protection were found the preferred outage mitigation methods.

C 2019 by the authors; licensee Growing Science, Canada

\section{Introduction}

The success of any industry depends on the continuous availability of the production system but attributable to the reasons such as power system reliability and quality issues, equipment failures due to the different causes, preventive maintenance schedules, strikes etc. can cause a substantial amount of downtime which ultimately reflects in the forms of lost revenues. Downtime as a consequence of electric power outages can cost a substantial amount of money to an industry. Power outages can impact the bottom line

* Corresponding author.

E-mail address: mangat84@gmail.com (H. S. Mangat) 
and affect ongoing business operations. An industrial sector is the backbone of every nation, which contributes a significant share towards the economy. In order to get the maximum returns, every industrialist dreams of a 100 percent reliability of the production system which practically cannot be achieved. As far as the power system reliability is concerned, there are broadly three major categories of reliability issues: planned outages, unplanned outages and load shedding which are responsible for the downtime in the industries. Some power outages are planned, as when maintenance and upgrades of the utility infrastructure are needed from time to time. But, at other times, any business possibly may face the outages of the unplanned nature caused by the bad weather conditions, animals in the live electricity lines, vehicle accidents, equipment failures, spikes etc. Unplanned outages can lead to conditions from which it may be hard to recover. Load shedding is a method to allocate demand for electricity across numerous power sources. It is used to reduce the stress on a main energy source when demand for electricity is greater than the main power source can supply which ultimately avert the disaster of the entire system. When the demand strains the capacity of the system and crossed the supply limits, it is necessary to follow a strategy that help to manage the way electricity is utilized in a business to condense this peak demand, pointedly dipping monthly utility costs, which is called load shedding. Load shedding is used by the utility during the peak usage periods of the electric power among different types of consumers. The demand for power is increasing day by day however the power systems are not being upgraded at the same pace resulting in an increase in probability of occurrence of power outages. A new and sophisticated production systems of the industries are still dependent on the age old power systems and poses a danger to the industries. Power reliability means availability of power and power quality related problems arise whenever conventional alternating current electric power deviates momentarily or continuously from established standards for voltage, frequency, and waveform (Schienbein \& DeSteese, 2002).

Punjab is situated in the northern region of India and all the sectors such as residential, commercial, industrial and agricultural are dependent on the electric power supply, which is being delivered by the standalone public utility company Punjab State Power Corporation Limited (PSPCL). As the present study is only concerned with the industrial sector, the aspects relevant to this sector are discussed here. A considerable work has been carried out on the impact of power outages on different sectors throughout the world. A majority of the studies adopted a customer survey approach as the primary method of conducting a study which covered only the economic aspect while ignoring the social aspect. The present study however used primarily an interview method to carry out a research and record the attitude of the textile industries towards the aspects related to power system reliability problems and its effects. The textile industry accounts for $19 \%$ of the total industrial production of Punjab and contributes about $38 \%$ of the total exports from the State. Moreover, Punjab, Haryana and Rajasthan collectively produce over 52 lakh bales $(1$ bale $=170 \mathrm{Kg}$ ) of cotton annually while consumption is less than 40 lakh bales (Oppurtunities in Textiles in Punjab, 2018). In India, studies related to performance of power systems and their effect on the different sectors are seldom. The research related to power system reliability issues have been carrying in the developing and developed countries for many years, however, India has continuously been lacking in this field. For enhancing the situation of the power systems, the regional level studies are needed to be carried out at the micro level focusing one industrial sector and its connected power system rather than considering the broad scenarios at the national level which further help to plan the specific targeted power systems. In the best of the authors' opinion, the use of the national level data for planning the power systems at the regional levels is not a good idea because some power systems are already behaving well and would not need any enhancements and others may require major modifications. Lawton et al. (2003) found that the mean aggregated cost faced by an "average" consumer for one hour summer afternoon outage was nearly $\$ 3$ for residential sector, $\$ 1,200$ for small-medium commercial and industrial sectors, and $\$ 82,000$ for large commercial and industrial sectors. SARI/Energy (2003) observed that as high as the annual loss of US\$ 81 million ( $0.65 \%$ of GDP) could occur with imposing of 300 hours of planned power outages experienced in 2001. The influence due to unplanned power outages could be as high as US\$ 47 million $(0.38 \%$ of GDP) in a typical year with 100 hours of unplanned power outages. This was found noteworthy economic loss specifically in contrast to the $4.5 \%$ to $5 \%$ average GDP growth that has occurred in Sri Lanka during the last few years. Wijayatunga and Jayalath 
(2004) observed that the overall planned outages in the industrial sector costs only about 60 percent of that associated with the unplanned outages. In some cases, like in glass industry, a self-generation was used for running the production and other regular operations and utility electric power is used as standby power which lead to not only add costs to the industrial output but also amplified emissions. Adenikinju (2005) identified the infrastructure as the main restraint to private sector development in Nigeria. As an outcome of the power outages, industries lost an average of 792 working hours in 1998. Around 35 percent of the industries stated having to completely stop production at one time or the other in the year as an effect of power outages. The industries experienced five to ten outages in a week, with each outage lasting for more than one hour. Kivikko et al. (2007) concluded that in non-working time the planned outages would in some cases be more harmful than unplanned outages as responded by the respondents from the Finland. In general, the monetary harm for a planned interruption was found about $80 \%$ of the harm of an unexpected interruption. Wijayatunga and Jayalath (2008) evaluated that $94 \%$ of the total energy not served was due to unplanned power outages and only $6 \%$ can be attributable to planned power outages. Nearby $13.6 \%$ of the industrial sector demand could not be met by the utilities due to these outages which rendered into $11.54 \%$ of the industrial sector GDP or $1.72 \%$ of Bangladesh's gross domestic product (GDP) in 2000-01. Baarsma and Hop (2009) measured the outage cost by using conjoint analysis and found that the social cost of the current Dutch level of reliability was such that one outage of two hours every four years was V2.80 on an average for every household and V33.10 on average for every SME firm. The total costs to Dutch society were almost V50 million. Bhargava et al. (2012) concluded that about $18.9 \%$ of the total cost of production was attributed to the energy cost among the interviewed manufacturing industries in Tanzania. As a result of erratic electricity supply, the total production was decreased and hence production costs were increased and only about $15 \%$ of the manufacturing industries can afford to raise the prices of the products to handle with the challenges arising from the sustained erratic power supply. Akinbola et al. (2017) concluded that electricity state which is a consequence of present government policies employs a negative effect on the industrial output, in the long run, affects the business viability. Carlsson et al. (2018) estimated the cost of power outages for micro, small, and medium-sized enterprises in Addis Ababa, Ethiopia, using a stated preference survey. The assessed willingness to pay for a decrease of one power outage attributed to increase in tariff rate by 16 percent. The willingness to pay for decreasing the average duration of an electric power outage by one hour corresponds to an increase of 33 percent. The compensating variation for a zero-outage situation corresponds to about three times the current electricity cost. The average total costs of electric power outages for the industries' were 2,293 ETB (US\$96) per month, which amounts to 3 percent of the firm's monthly sales and equates to about 61 percent of the average monthly cost from using backup generators. Oyeyemi et al. (2018) observed that, irregular electric power had been a foremost problem to output growth in the manufacturing sector of Nigeria. The unstable electricity supply has brought about the acquisition of power backup supplies in the forms of generators or inverters, which adds to the existing costs and hence makes the production more expensive. A review of literature revealed that the customer survey approach was quite popular for conducting the studies related to power systems and hence authors used the same with an exception that no mathematical calculation was performed, instead the questions with ordinal scale were used to get the responses. This approach made the study easy and opened the other dimensions related to the effects of power systems on the different decisions of the firms.

\section{Material and methods}

A regional level survey was performed in which influence of the different power system reliability issues on the crucial future decisions was measured using the questionnaire having seven-point Likert item scale. This approach of conducting study at the regional level focusing the one particular industrial sector i.e. textiles was found beneficial as it reflects the image of the utility from the consumer's prospective, hence reduces biasness. As the industries responded bearing in mind their connected power systems, the more accurate results were obtained. In order to simplify the scenario for the respondents, instead of the questions that demands calculations, the ordinal and nominal category type questions were used in the 
questionnaire. It was found that the questions related to the costs of the industries were not being answered properly, therefore, decision was made to remove these type of questions from the questionnaire schedule during the pilot testing phase. Over a period of two years from April 2015- April 2017, 148 completed responses were attained out of the 400 randomly selected industries from population list of 1163 registered textile industries. The conducted study aims at the mindset of the textile consumers of Punjab (India) about the futuristic decisions and strategies effected by the major power system reliability concerns such as planned outages, unplanned outages and load shedding/power rationing/rolling blackouts.

\section{Results and discussions}

A SPSS and Microsoft Excel software were used to perform the statistical analysis and the visualization of the data, respectively. A SPSS syntax was used to calculate the Krippendorff's alpha-interrater reliability for the related samples designs and individual levels of the independent variable for the variables under part B of the survey (Krippendorff, 2011) and (Hayes, 2007). An internal consistency-Cronbach's alpha was also calculated for the independent sample design (Part B). For the part B, a Wilcox-Mann Whitney Test was applied to determine if there are differences between two groups on a seven point Likert item scale ordinal dependent variable. Also, for the independent sample design, the effect sizes were calculated using the Mann Whitney U Statistics. The zone with values of effect sizes from 0.0600.110 is known as the zone of intermediate effect and values higher than 0.140 displays the large effect as per (Lenhard \& Lenhard, 2016). Further, for the variables under the parts O, I, (Ii-Iii-Iiii) and L, a Friedman test- non-parametric one-way repeated measures ANOVA test was used to determine whether or not there are any statistically significant differences between the distributions of three or more related groups. The groups are related as they comprise the same cases (e.g., respondents) in each group and each group characterizes a repeated measurement on the same dependent variable. As a post hoc test, Dunn's Bonferroni test was applied to know further the statistically significant difference between the pairs formed by the different dependent variables. A Kendall's $W$ applied here ranges between 0 and 1 (depicting agreement level among the respondents).

Table 1

Interrater reliability and internal consistency assessment of the different sections of the survey.

\begin{tabular}{|c|c|c|c|c|c|c|c|c|c|}
\hline \multirow{2}{*}{\multicolumn{2}{|c|}{$\begin{array}{c}\text { Krippendorff's Alpha } \\
\text { Section B }\end{array}$}} & \multirow{3}{*}{ Section $\mathrm{O}$} & \multicolumn{4}{|c|}{ Krippendorff's Alpha } & \multicolumn{3}{|c|}{ Cronbach's Alpha } \\
\hline & & & \multirow{2}{*}{ Section I } & \multirow{2}{*}{ Section Ii } & \multirow{2}{*}{ Section Iii } & \multirow{2}{*}{ Section Iiii } & \multirow{2}{*}{ Part L } & \multirow{2}{*}{\multicolumn{2}{|c|}{ Part B }} \\
\hline Micro & Small & & & & & & & & \\
\hline 0.66 & 0.67 & 0.72 & 0.75 & 0.64 & 0.82 & 0.81 & 0.72 & & 0.86 \\
\hline \multicolumn{10}{|c|}{ Krippendorff's Alpha } \\
\hline $\begin{array}{l}\text { I1i-I1ii- } \\
\text { I1iii }\end{array}$ & $\begin{array}{l}\text { I2i-I2ii- } \\
\text { I2iii }\end{array}$ & $\begin{array}{l}\text { I3i-I3ii- } \\
\text { I3iii }\end{array}$ & $\begin{array}{l}\text { I4i-I4ii- } \\
\text { I4iii }\end{array}$ & $\begin{array}{l}\text { I5i-I5ii- } \\
\text { I5iii }\end{array}$ & $\begin{array}{l}\text { I6i-I6ii- } \\
\text { I6iii }\end{array}$ & $\begin{array}{l}\text { I7i-I7ii- } \\
\text { I7iii }\end{array}$ & $\begin{array}{l}\text { I8i-I8ii- } \\
\text { I8iii }\end{array}$ & $\begin{array}{l}\text { I9i-I9ii- } \\
\text { I9iii }\end{array}$ & $\begin{array}{l}\text { I10i-I10ii- } \\
\text { I10iii }\end{array}$ \\
\hline 0.80 & 0.74 & 0.75 & 0.63 & 0.69 & 0.38 & 0.50 & 0.39 & 0.77 & 0.73 \\
\hline
\end{tabular}

Section B: Respondents were asked about the level of concern on a seven-point Likert item scale towards the type of power system reliability \& quality issues mentioned below from B1to B9 on your business?

\begin{tabular}{c|c|c|c|c|cc|c}
\hline 1 & 2 & 3 & 5 & 6 & 7 \\
\hline $\begin{array}{c}\text { Not at all } \\
\text { concerned }\end{array}$ & $\begin{array}{c}\text { Slightly } \\
\text { concerned }\end{array}$ & $\begin{array}{c}\text { Somewhat } \\
\text { concerned }\end{array}$ & $\begin{array}{c}\text { Moderately } \\
\text { concerned }\end{array}$ & $\begin{array}{c}\text { Considerably } \\
\text { concerned }\end{array}$ & $\begin{array}{c}\text { Highly } \\
\text { concerned }\end{array}$ & $\begin{array}{c}\text { Extremely } \\
\text { concerned }\end{array}$ \\
\hline
\end{tabular}

Wilcox-Mann-Whitney Test (WMW)- Null-Hypothesis: The distribution of the dependent variables from B1 to B9 is the same across the categories of an independent variable- size of the industry (categorization by the national criteria on industrial size)

B1. System voltage fluctuations B4. System switching/operating errors B7. System supply deficit (insufficient generation) leads to load shedding
B2. System frequency fluctuations B5. System protection/relaying problems B8. Unplanned power outages
B3. System transient faults

B6. System transmission overloading

B9. Planned power outages 
Table 2

Wilcox-Mann Whitney Test Statistics with effect size and descriptive statistics- Level of concern towards the power system reliability and quality issues based on the size of the industry.

\begin{tabular}{|c|c|c|c|c|c|c|c|c|}
\hline \multirow[b]{2}{*}{ DV } & \multirow[b]{2}{*}{ IV-Size } & \multirow[b]{2}{*}{$\begin{array}{l}\text { Mean } \\
\text { Rank }\end{array}$} & \multirow[b]{2}{*}{$\begin{array}{l}\text { Sum of } \\
\text { Ranks }\end{array}$} & \multirow[b]{2}{*}{ Mean } & \multirow[b]{2}{*}{ Std Dev. } & \multicolumn{3}{|c|}{ Percentiles } \\
\hline & & & & & & 25 th & $\begin{array}{c}\text { 50th } \\
\text { (Median) }\end{array}$ & 75th \\
\hline \multirow{4}{*}{ B1 } & 1. Micro Scale & 90.32 & 7406.50 & 3.73 & 1.432 & 2.75 & 3.00 & 5.00 \\
\hline & 2. Small Scale & 54.84 & 3619.50 & 2.48 & 0.864 & 2.00 & 3.00 & 3.00 \\
\hline & \multirow{2}{*}{ Test Statistics } & $\mathrm{U}$ & W & Z & $\mathrm{P}$ & $\Pi 2$ & S.E & \multirow{2}{*}{ Significan } \\
\hline & & 1408.500 & 3619.500 & -5.175 & 0.000 & 0.169 & 250.729 & \\
\hline \multirow{4}{*}{ B2 } & \multirow{2}{*}{$\begin{array}{l}\text { 1. Micro Scale } \\
\text { 2. Small Scale }\end{array}$} & 83.12 & 6815.50 & 2.40 & 0.751 & 2.00 & 2.00 & 3.00 \\
\hline & & 63.80 & 4210.50 & 2.03 & 0.784 & 1.00 & 2.00 & 3.00 \\
\hline & \multirow{2}{*}{ Test Statistics } & $\mathrm{U}$ & W & Z & $\mathrm{P}$ & $\eta 2$ & S.E & \multirow{2}{*}{ Significant } \\
\hline & & 1999.500 & 4210.500 & -2.930 & 0.003 & 0.05 & 241.163 & \\
\hline \multirow{4}{*}{ B3 } & \multirow{2}{*}{$\begin{array}{l}\text { 1. Micro Scale } \\
\text { 2. Small Scale }\end{array}$} & 85.00 & 6970.00 & 2.93 & 0.782 & 2.00 & 3.00 & \multirow{2}{*}{$\begin{array}{l}3.00 \\
3.00\end{array}$} \\
\hline & & 61.45 & 4056.00 & 2.32 & 1.040 & 1.00 & 2.50 & \\
\hline & \multirow{2}{*}{ Test Statistics } & $\mathrm{U}$ & W & Z & $\mathrm{P}$ & $\eta 2$ & S.E & \multirow{2}{*}{ Significan } \\
\hline & & 1845.000 & 4056.000 & -3.538 & 0.000 & 0.075 & 243.384 & \\
\hline \multirow{4}{*}{ B4 } & 1. Micro Scale & 89.64 & 7350.50 & 4.74 & 1.016 & 4.00 & 5.00 & 6.00 \\
\hline & 2. Small Scale & 55.69 & 3675.50 & 3.83 & 0.904 & 3.00 & 4.00 & 5.00 \\
\hline & \multirow{2}{*}{ Test Statistics } & U & $\mathrm{W}$ & $\mathrm{Z}$ & $\mathrm{P}$ & $\Pi 2$ & S.E & \multirow{2}{*}{ Significant } \\
\hline & & 1464.500 & 3675.500 & -4.974 & 0.000 & 0.155 & 249.588 & \\
\hline \multirow{4}{*}{ B5 } & \multirow{2}{*}{$\begin{array}{l}\text { 1. Micro Scale } \\
\text { 2. Small Scale }\end{array}$} & 94.12 & 7717.50 & 5.50 & 0.805 & 5.00 & 5.00 & \multirow{2}{*}{$\begin{array}{l}6.00 \\
5.00\end{array}$} \\
\hline & & 50.13 & 3308.50 & 4.36 & 0.955 & 4.00 & 4.00 & \\
\hline & \multirow{2}{*}{ Test Statistics } & $\mathrm{U}$ & W & Z & $\mathrm{P}$ & $\prod 2$ & S.E & Sionificont \\
\hline & & 1097.500 & 3308.500 & -6.513 & 0.000 & 0.26 & 246.976 & Significant \\
\hline & 1. Micro Scale & 89.91 & 7372.50 & 4.83 & 0.927 & 4.00 & 5.00 & 5.00 \\
\hline & 2. Small Scale & 55.36 & 3653.50 & 3.83 & 1.131 & 3.00 & 4.00 & 5.00 \\
\hline B6 & Tect Statictice & U & W & Z & $\mathrm{P}$ & $\eta 2$ & S.E & Sionificont \\
\hline & I est Statistics & 1442.500 & 3653.500 & -5.062 & 0.000 & 0.161 & 249.622 & Significant \\
\hline & 1. Micro Scale & 86.31 & 7077.50 & 6.30 & 0.661 & 6.00 & 6.00 & 7.00 \\
\hline & 2. Small Scale & 59.83 & 3948.50 & 5.82 & 0.700 & 5.00 & 6.00 & 6.00 \\
\hline B7 & Tect Statictics & U & W & Z & $\mathrm{P}$ & $\prod 2$ & S.E & Sionificont \\
\hline & I est Statistics & 1737.500 & 3948.500 & -4.073 & 0.000 & 0.094 & 237.761 & Significant \\
\hline & 1. Micro Scale & 82.18 & 6738.50 & 6.41 & 0.684 & 6.00 & 7.00 & 7.00 \\
\hline & 2. Small Scale & 64.96 & 4287.50 & 6.08 & 0.810 & 6.00 & 6.00 & 7.00 \\
\hline B8 & Tect Statictics & U & W & Z & $\mathrm{P}$ & $\prod 2$ & S.E & Sionificont \\
\hline & I est Statistics & 2076.500 & 4287.500 & -2.644 & 0.008 & 0.04 & 238.085 & Significant \\
\hline & 1. Micro Scale & 84.76 & 6950.00 & 4.43 & 1.207 & 4.00 & 4.00 & 5.00 \\
\hline & 2. Small Scale & 61.76 & 4076.00 & 3.77 & 1.187 & 3.00 & 4.00 & 4.25 \\
\hline B9 & & U & W & Z & $\mathrm{P}$ & $\Pi 2$ & S.E & \\
\hline & Test Statistics & 1865.000 & 4076.000 & -3.333 & 0.001 & 0.071 & 252.318 & Significant \\
\hline
\end{tabular}

A Mann-Whitney $U$ test was run to determine if there were differences in level of concern score towards the power system reliability and quality issues between micro and small scale textile industries. Distributions of the level of concern for micro and small scale textile industries were not similar, as assessed by visual inspection as shown in Fig. 1. Level of concern scores for micro scale textile industries were statistically significantly higher than for small scale textile industries for all the variables from B1 to B9, which is clearly evident from the Wilcox-Mann Whitney Test Statistics as shown in the Table 2. The mean ranks and sum of ranks for micro-scale industries were found higher than the small scale textile industries for all the variables. The effect sizes $\left(\Pi^{2}\right)$ using the Mann-Whitney U statistics were calculated and were found in the zone of large effect for the variables B1, B4, B5 and B6, however, the effect sizes for the variables B3, B7 and B9 were seen in the area of intermediate effect, which are considered the zones of desired effects. Only for the variables B2 and B8, the effect size were found in the zone of small effect. The detailed descriptive statistics showing median, mean, standard deviation and percentiles are shown in the Table 2. As shown in the Fig. 2 depicting the Frequency Distribution Visual, the high rating on seven point Likert item scale towards the power system reliability issues "unplanned outages (B8)" 
and "planned outages (B9)" than the power system quality issues (B1-B6), revealed that industries were very highly concerned towards the electric power reliability problems than the quality issues. Also, the variable "system supply deficit (insufficient generation) leads to load shedding (B7)" were rated considerably higher on the scale which exposed that the industries were also not spared from the load shedding during the past years. The whole analysis exposed that the micro scale industries have shown more concern towards both the power system reliability and quality issues than the small scale industries, however, the power quality issues were not rated that high on the level of concern scale as compared to the reliability issues.

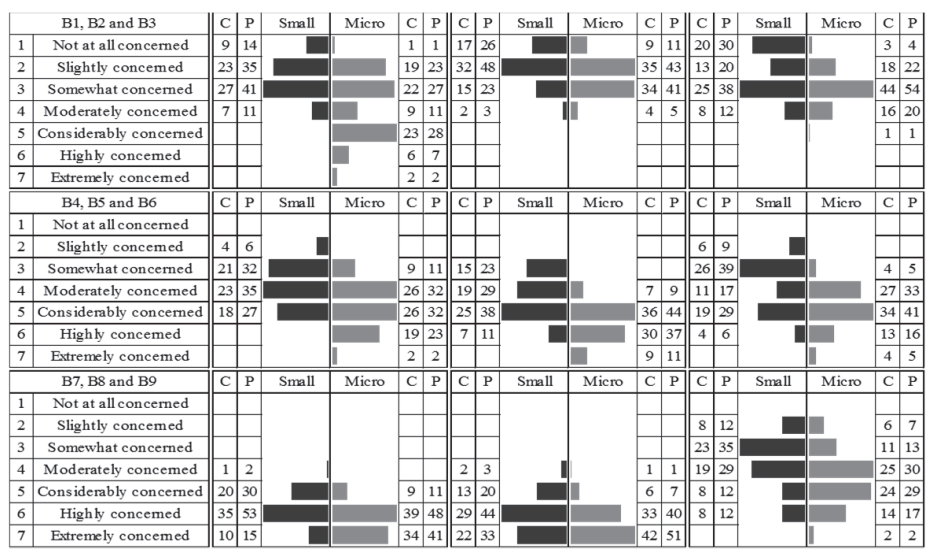

Fig. 1. Frequency Distribution Visual- Level of concern towards the power system reliability and quality issues based on the size of the industry

Section O: Respondents were asked about the level of disruptiveness on a seven-point Likert item scale towards the occurrence of one hour outage due to the reliability issues of different nature mentioned below from $\mathrm{O} 1$ to $\mathrm{O} 5$ on your business.

\begin{tabular}{cccccccc}
\hline 1 & 2 & 3 & 4 & 5 & 6 & 7 \\
\hline $\begin{array}{c}\text { Not at all } \\
\text { disruptive }\end{array}$ & $\begin{array}{c}\text { Slightly } \\
\text { disruptive }\end{array}$ & $\begin{array}{c}\text { Somewhat } \\
\text { disruptive }\end{array}$ & $\begin{array}{c}\text { Moderately } \\
\text { disruptive }\end{array}$ & $\begin{array}{c}\text { Considerably } \\
\text { disruptive }\end{array}$ & $\begin{array}{c}\text { Highly } \\
\text { disruptive }\end{array}$ & $\begin{array}{c}\text { Completely } \\
\text { disruptive }\end{array}$ \\
\hline
\end{tabular}

Friedman Test- Null-Hypothesis: The distributions of the variables from $\mathrm{O} 1$ to $\mathrm{O} 5$ are the same. The same respondents were measured on a different variable, but using the same seven-point Likert item disruptiveness scale, Friedman test was found suitable to determine any difference between their disruptiveness levels.

O1. Unplanned power outage-1 hour scenario

O2. Dangerous advance warning, planned power outage-1 hour scenario

O3. Safe advance warning, planned power outage- 1 hour scenario

Table 3

Friedman Q and descriptive statistics- Level of disruptiveness by 1 hour reliability issue scenarios

\begin{tabular}{|c|c|c|c|c|c|c|c|c|c|c|c|c|c|}
\hline \multicolumn{7}{|c|}{ | Test Statistics- Friedman's Q | Chi-Square $=468.929 \mid$} & \multicolumn{7}{|c|}{$\mid$ Kendal's W $=\mathbf{0 . 7 9 2} \mid$} \\
\hline \multicolumn{7}{|c|}{$\mid$ Asymp. Sig. $(p-$ Value $)=0.000 \mid$} & \multicolumn{7}{|c|}{$\mathrm{N}=148$, Degree of Freedom $=04 \mid$} \\
\hline \multirow{3}{*}{$\begin{array}{c}\text { Dependent } \\
\text { Variables }\end{array}$} & \multirow{3}{*}{$\begin{array}{l}\text { Mean } \\
\text { Rank }\end{array}$} & \multirow{2}{*}{\multicolumn{3}{|c|}{ Percentiles }} & \multirow{3}{*}{ Mean } & \multirow{3}{*}{$\begin{array}{l}\text { Std. } \\
\text { Dev. }\end{array}$} & 1 & 2 & 3 & 4 & 5 & 6 & 7 \\
\hline & & & & & & & \multirow{2}{*}{ 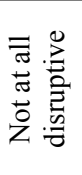 } & \multirow{2}{*}{ 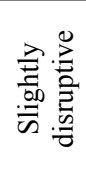 } & \multirow{2}{*}{ 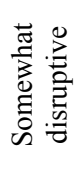 } & \multirow{2}{*}{ 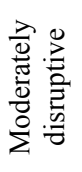 } & \multirow{2}{*}{ 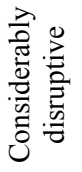 } & \multirow{2}{*}{ 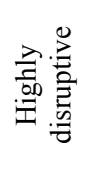 } & \multirow{2}{*}{ 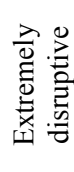 } \\
\hline & & 25 th & $\begin{array}{c}50 \text { th } \\
\text { (Median) }\end{array}$ & 75 th & & & & & & & & & \\
\hline O1 & 4.55 & 6.00 & 6.00 & 7.00 & 6.35 & 0.479 & $0 \%$ & $0 \%$ & $0 \%$ & $0 \%$ & $0 \%$ & $65 \%$ & $35 \%$ \\
\hline $\mathbf{O 2}$ & 3.79 & & 6.00 & 6.00 & & & $0 \%$ & $0 \%$ & $0 \%$ & $0 \%$ & $20 \%$ & $78 \%$ & $2 \%$ \\
\hline $\mathbf{O 3}$ & 3.18 & 5.00 & 5.00 & 6.00 & 5.47 & 0.527 & $0 \%$ & $0 \%$ & $0 \%$ & $1 \%$ & $50 \%$ & $49 \%$ & $0 \%$ \\
\hline 04 & 2.27 & 5.00 & 5.00 & 5.00 & 4.96 & 0.435 & $0 \%$ & $0 \%$ & $0 \%$ & $11 \%$ & $81 \%$ & $7 \%$ & $0 \%$ \\
\hline O5 & 1.22 & 4.00 & 4.00 & 4.00 & 4.14 & 0.543 & $0 \%$ & $0 \%$ & $9 \%$ & $69 \%$ & $22 \%$ & $0 \%$ & $0 \%$ \\
\hline
\end{tabular}


Table 4

Bonferroni Dunn's post hoc- Level of disruptiveness by 1 hour reliability issue scenarios

\begin{tabular}{|c|c|c|c|c|c|}
\hline Sample1-Sample2 & Test Statistic & Std. Error & Std. Test Statistic & Sig. & Adj. Sig. ${ }^{a}$ \\
\hline 05-04 & 1.047 & 0.184 & 5.698 & 0.000 & 0.000 \\
\hline O5-03 & 1.956 & 0.184 & 10.642 & 0.000 & 0.000 \\
\hline O5-02 & 2.568 & 0.184 & 13.969 & 0.000 & 0.000 \\
\hline 05-01 & 3.331 & 0.184 & 18.123 & 0.000 & 0.000 \\
\hline O4-03 & 0.909 & 0.184 & 4.944 & 0.000 & 0.000 \\
\hline O4-02 & 1.520 & 0.184 & 8.271 & 0.000 & 0.000 \\
\hline 04-01 & 2.284 & 0.184 & 12.425 & 0.000 & 0.000 \\
\hline O3-O2 & 0.611 & 0.184 & 3.327 & 0.001 & 0.009 \\
\hline O3-01 & 1.375 & 0.184 & 7.481 & 0.000 & 0.000 \\
\hline O2-01 & 0.764 & 0.184 & 4.154 & 0.000 & 0.000 \\
\hline
\end{tabular}

Each row tests the null hypothesis that the Sample 1 and Sample 2 distributions are the same.

Asymptotic significances (2-sided tests) are displayed. The significance level is .05.

a. Significance values have been adjusted by the Bonferroni correction for multiple tests.

Table 3 and Table 4 show the Friedman statistics including the major descriptive statistics, and Bonferroni Dunn's post hoc analysis statistics, respectively. The variables shown in Table 3 are arranged in the descending order of their mean ranks obtained by running the Friedman test in SPSS. A Friedman test was run to determine whether or not there were differences in disruptiveness scores among the different variables from $\mathrm{O} 1$ to O5. Pairwise comparisons were performed (SPSS Statistics 24) with a Bonferroni correction for multiple comparisons. Level of disruptiveness score was statistically significantly different among the different variables, Friedman's $Q$ or $\chi 2(4)=468.929, p=0.000$. Post hoc analysis revealed statistically significant differences among the level of disruptiveness scores for all the possible pairwise combinations formed by the dependent variables. If the significance level without Bonferroni adjustment is used the significance level used here is 0.005 , obtained by the original $p$-value of 0.05 divided by the number of possible pairwise combinations which are ten (10) for the present scenario as shown in the Table 4. However, for the easy reference to check the significance level, the last column shown in the Table 4 here contains the adjusted p-values obtained after Bonferroni correction. The mean ranks for the variables unplanned power outages- 1 hour scenario $(\mathrm{O} 1)$ and dangerous advance warning (short period advance warning), planned power outage-1 hour scenario (O2) were found 4.55 and 3.79, which were noticeably higher as compared to other variables, revealing that the level of disruptiveness was considerably larger than the other 1 hour scenarios. The mean rank of 1.22 was obtained for a variable short length load shedding (Peak load days)-1 hour scenario (O5), which showed that this variable was scored substantially low on seven-point Likert item scale of level of disruptiveness, depicting that disruptiveness was quite low as compared to other 1 hour scenarios. The mean ranks for the variables, safe advance warning, planned power outage- 1 hour scenario (O3) and long length load shedding (Weekly off days)1 hour scenario $(\mathrm{O} 4)$, were 3.18 and 2.27, respectively. The median values for the variables $\mathrm{O} 1, \mathrm{O} 2, \mathrm{O} 3$, $\mathrm{O} 4$ and $\mathrm{O} 5$ were 6, 6, 5, 5 and 4, respectively. A fairly good level of agreement was seen as depicted by the Kendal's W value of 0.792 , among the respondents.

Section I: Respondents were asked about the level of importance on a seven-point Likert item scale given towards the company's future plans and development mentioned below from I1 to I10.

\begin{tabular}{cc|ccc|cc}
\hline 1 & 2 & 3 & 4 & 5 & 6 & 7 \\
\hline $\begin{array}{c}\text { Not at all } \\
\text { important }\end{array}$ & $\begin{array}{c}\text { Slightly } \\
\text { important }\end{array}$ & $\begin{array}{c}\text { Somewhat } \\
\text { important }\end{array}$ & $\begin{array}{c}\text { Moderately } \\
\text { important }\end{array}$ & $\begin{array}{c}\text { Considerably } \\
\text { important }\end{array}$ & $\begin{array}{c}\text { Highly } \\
\text { important }\end{array}$ & $\begin{array}{c}\text { Extremely } \\
\text { important }\end{array}$ \\
\hline
\end{tabular}

Friedman Test- Null-Hypothesis: The distributions of the variables from I1 to I10 are the same. As the same respondents were measured on a different variable, but using the same seven-point Likert item importance scale, Friedman test was found suitable to determine any difference between their importance levels.

I1. Diversification

I2. Growth or expansion of existing unit

I3. Moving industries to other state with good energy facilities

I4. Outsourcing at high cost, change in policy (making to buy)

I5. Supplier selection and material procurement plan
I6. Venturing new markets

I7. Procurement of bank loans

I8. Change in process design based on low energy requirement

I9. Like to go for costly alternative energy sources

I10. Enhancing the reserve and inventory level 
Table 5

Friedman Q and descriptive statistics- Level of importance towards the future plans and strategies

| Test Statistics- Friedman's Q | Chi-Square= 1035.016 |

$\mid$ Asymp. Sig. $(p-$ Value $)=0.000 \mid$

| Kendall's W= 0.777 |

\begin{tabular}{|c|c|c|c|c|c|c|c|c|c|c|c|c|c|}
\hline & \multirow{4}{*}{$\begin{array}{l}\text { Mean } \\
\text { Rank }\end{array}$} & \multirow{3}{*}{\multicolumn{3}{|c|}{ Percentiles }} & & & \multicolumn{7}{|c|}{ N-148, Degree or Freedom- - } \\
\hline \multirow{3}{*}{$\begin{array}{l}\text { Dependent } \\
\text { Variables }\end{array}$} & & & & & \multirow{3}{*}{ Mean } & \multirow{3}{*}{$\begin{array}{l}\text { Std. } \\
\text { Dev. }\end{array}$} & 1 & 2 & 3 & 4 & 5 & 6 & 7 \\
\hline & & & & & & & \multirow{2}{*}{ 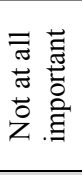 } & \multirow{2}{*}{ 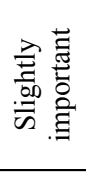 } & \multirow{2}{*}{ 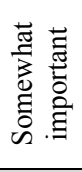 } & \multirow{2}{*}{ 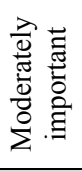 } & \multirow{2}{*}{ 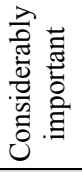 } & \multirow{2}{*}{ 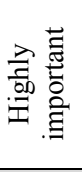 } & \multirow{2}{*}{ 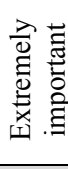 } \\
\hline & & 25 th & $\begin{array}{c}\text { 50th } \\
\text { (Median) }\end{array}$ & 75 th & & & & & & & & & \\
\hline I2 & 9.26 & 6.00 & 6.00 & 6.00 & 6.22 & 0.429 & $0 \%$ & $0 \%$ & $0 \%$ & $0 \%$ & $1 \%$ & $77 \%$ & $22 \%$ \\
\hline I9 & 8.06 & 5.00 & 6.00 & 6.00 & 5.72 & 0.569 & $0 \%$ & $0 \%$ & $0 \%$ & $1 \%$ & $32 \%$ & $62 \%$ & $5 \%$ \\
\hline I7 & 7.33 & 5.00 & 5.00 & 6.00 & 5.45 & 0.538 & $0 \%$ & $0 \%$ & $0 \%$ & $2 \%$ & $51 \%$ & $47 \%$ & $0 \%$ \\
\hline I3 & 7.01 & 5.00 & 5.00 & 6.00 & 5.34 & 0.531 & $0 \%$ & $0 \%$ & $0 \%$ & $3 \%$ & $60 \%$ & $37 \%$ & $0 \%$ \\
\hline I1 & 6.01 & 5.00 & 5.00 & 5.00 & 5.00 & 0.559 & $0 \%$ & $0 \%$ & $0 \%$ & $16 \%$ & $69 \%$ & $16 \%$ & $0 \%$ \\
\hline I5 & 4.83 & 4.00 & 5.00 & 5.00 & 4.58 & 0.547 & $0 \%$ & $0 \%$ & $0 \%$ & $45 \%$ & $53 \%$ & $3 \%$ & $0 \%$ \\
\hline I10 & 4.62 & 4.00 & 5.00 & 5.00 & 4.51 & 0.633 & $0 \%$ & $0 \%$ & $5 \%$ & $43 \%$ & $50 \%$ & $3 \%$ & $0 \%$ \\
\hline I8 & 4.41 & 4.00 & 4.00 & 5.00 & 4.42 & 0.595 & $0 \%$ & $0 \%$ & $4 \%$ & $51 \%$ & $43 \%$ & $1 \%$ & $0 \%$ \\
\hline I6 & 2.11 & 3.00 & 3.00 & 4.00 & 3.34 & 0.544 & $0 \%$ & $2 \%$ & $63 \%$ & $34 \%$ & $1 \%$ & $0 \%$ & $0 \%$ \\
\hline I4 & 1.36 & 3.00 & 3.00 & 3.00 & 2.89 & 0.406 & $0 \%$ & $14 \%$ & $82 \%$ & $3 \%$ & $0 \%$ & $0 \%$ & $0 \%$ \\
\hline
\end{tabular}

Table 6

Bonferroni Dunn's post hoc- Level of importance towards the future plans and strategies

\begin{tabular}{|c|c|c|c|c|c|c|c|c|c|c|c|}
\hline $\begin{array}{l}\text { Sample1- } \\
\text { Sample2 }\end{array}$ & $\begin{array}{l}\text { Test Sta- } \\
\text { tistic }\end{array}$ & $\begin{array}{c}\text { Std. } \\
\text { Error }\end{array}$ & $\begin{array}{l}\text { Std. Test } \\
\text { Statistic }\end{array}$ & Sig. & $\begin{array}{l}\text { Adj. } \\
\text { Sig. }\end{array}$ & $\begin{array}{c}\text { Sample1- } \\
\text { Sample2 }\end{array}$ & $\begin{array}{l}\text { Test Sta- } \\
\text { tistic }\end{array}$ & $\begin{array}{l}\text { Std. } \\
\text { Error }\end{array}$ & $\begin{array}{l}\text { Std. Test } \\
\text { Statistic }\end{array}$ & Sig. & $\begin{array}{l}\text { Adj. } \\
\text { Sig. }\end{array}$ \\
\hline I4-I6 & $-\mathbf{- 0 . 7 5 0}$ & 0.352 & -2.131 & 0.033 & 1.000 & I8-I2 & 4.855 & 0.352 & 13.794 & 0.000 & 0.000 \\
\hline I4-I8 & -3.044 & 0.352 & -8.649 & 0.000 & 0.000 & I10-I5 & 0.213 & 0.352 & 0.605 & 0.545 & 1.000 \\
\hline I4-I10 & -3.260 & 0.352 & -9.263 & 0.000 & 0.000 & I10-I1 & 1.389 & 0.352 & 3.945 & 0.000 & 0.004 \\
\hline I4-I5 & -3.473 & 0.352 & -9.868 & 0.000 & 0.000 & I10-I3 & 2.389 & 0.352 & 6.786 & 0.000 & 0.000 \\
\hline I4-I1 & 4.649 & 0.352 & 13.208 & 0.000 & 0.000 & I10-I7 & 2.706 & 0.352 & 7.689 & 0.000 & 0.000 \\
\hline I4-I3 & 5.649 & 0.352 & 16.049 & 0.000 & 0.000 & I10-I9 & 3.436 & 0.352 & 9.762 & 0.000 & 0.000 \\
\hline I4-I7 & -5.966 & 0.352 & -16.952 & 0.000 & 0.000 & I10-I2 & 4.639 & 0.352 & 13.179 & 0.000 & 0.000 \\
\hline I4-I9 & -6.696 & 0.352 & -19.025 & 0.000 & 0.000 & $I 5-I 1$ & 1.176 & 0.352 & 3.340 & 0.001 & 0.038 \\
\hline I4-I2 & 7.899 & 0.352 & 22.442 & 0.000 & 0.000 & I5-I3 & 2.176 & 0.352 & 6.182 & 0.000 & 0.000 \\
\hline I6-I8 & -2.294 & 0.352 & -6.518 & 0.000 & 0.000 & I5-I7 & -2.493 & 0.352 & -7.084 & 0.000 & 0.000 \\
\hline I6-I10 & -2.510 & 0.352 & -7.132 & 0.000 & 0.000 & I5-I9 & -3.223 & 0.352 & -9.157 & 0.000 & 0.000 \\
\hline I6-I5 & 2.723 & 0.352 & 7.737 & 0.000 & 0.000 & I5-I2 & 4.426 & 0.352 & 12.574 & 0.000 & 0.000 \\
\hline I6-I1 & 3.899 & 0.352 & 11.077 & 0.000 & 0.000 & I1-I3 & -1.000 & 0.352 & -2.841 & 0.004 & 0.202 \\
\hline I6-I3 & 4.899 & 0.352 & 13.918 & 0.000 & 0.000 & I1-I7 & -1.318 & 0.352 & -3.744 & 0.000 & 0.008 \\
\hline I6-I7 & -5.216 & 0.352 & -14.821 & 0.000 & 0.000 & I1-I9 & -2.047 & 0.352 & -5.817 & 0.000 & 0.000 \\
\hline I6-I9 & -5.946 & 0.352 & -16.894 & 0.000 & 0.000 & I1-I2 & -3.250 & 0.352 & -9.234 & 0.000 & 0.000 \\
\hline I6-I2 & 7.149 & 0.352 & 20.311 & 0.000 & 0.000 & I3-I7 & -0.318 & 0.352 & -0.902 & 0.367 & 1.000 \\
\hline I8-I10 & -0.216 & 0.352 & -0.614 & 0.539 & 1.000 & I3-I9 & -1.047 & 0.352 & -2.976 & 0.003 & 0.132 \\
\hline I8-I5 & 0.429 & 0.352 & 1.219 & 0.223 & 1.000 & I3-I2 & 2.250 & 0.352 & 6.393 & 0.000 & 0.000 \\
\hline I8-I1 & 1.605 & 0.352 & 4.559 & 0.000 & 0.000 & I7-I9 & -0.730 & 0.352 & -2.073 & 0.038 & 1.000 \\
\hline I8-I3 & 2.605 & 0.352 & 7.401 & 0.000 & 0.000 & I7-I2 & 1.932 & 0.352 & 5.491 & 0.000 & 0.000 \\
\hline I8-I7 & 2.922 & 0.352 & 8.303 & 0.000 & 0.000 & I9-I2 & 1.203 & 0.352 & 3.417 & 0.001 & 0.028 \\
\hline I8-I9 & -3.652 & 0.352 & -10.376 & 0.000 & 0.000 & & & . & ant p-va & $\mathrm{s}$ for $\mathrm{pc}$ & \\
\hline
\end{tabular}

Each row tests the null hypothesis that the Sample 1 and Sample 2 distributions are the same.

Asymptotic significances (2-sided tests) are displayed. The significance level is .05 .

a. Significance values have been adjusted by the Bonferroni correction for multiple tests.

Table 5 and Table 6 shown here are representing the test statistics of Friedman and Bonferroni Dunn's post hoc, respectively. The key descriptive statistics are also shown in the Table 5. A Friedman test was applied to identify whether or not there were differences in level of importance scores among the different variables from I1 to I10. A pairwise comparisons were performed with a Bonferroni correction for multiple comparisons. Level of importance score was statistically significantly different among the different variables, Friedman's Q or $\chi 2(4)=1035.016, p=0.000$. Post hoc analysis revealed statistically significant differences among the level of importance scores for the possible pairwise combinations formed by the dependent variables. If the significance level without Bonferroni adjustment is used, the significance 
level of 0.001 is used here, obtained by the original p-value of 0.05 divided by the number of possible pairwise combinations which are forty five (45) for the present scenario. Eight pairwise combinations were found insignificant, which were I4-I6, I10-I5, I1-I3, I3-I7, I8-I10, I3-I9, I8-I5 and I7-I9 as their pvalues were found higher than 0.001 . The adjusted $p$-values in last column eliminates the use of this method. These pairwise combinations have shown the non-significant results but a much high value of Kendal's W i.e. 0.777 revealed that the high level of agreement was found among the respondents while scoring on seven-point Likert item scale, which can be clearly seen from the Table 5 in which the variables are arranged in the descending order based on their mean ranks. The very high mean ranks of 9.26, 8.06, 7.33 and 7.01 for the variables, growth or expansion of existing unit (I2), like to go for costly alternative energy sources (I9), procurement of bank loans (I7) and moving industries to other state with good energy facilities (I3), respectively, exposed that respondents shown very high level of importance towards these future plans or decisions as compared to others. The median values for the I2, I9, I7 and I3 were found 6, 6, 5 and 5, respectively. For the variables, outsourcing at high cost (I4) and venturing new markets venturing new markets (I6), very low means ranks of 1.36 and 2.11 portrayed the least importance given by the respondents towards these variables. The median values for both the variables I4 and I6 were found three. The mean ranks for the variables, diversification (I1), supplier selection and material procurement plan (I5), enhancing the reserve and inventory level (I10) and change in process design based on low energy requirement (I8), rated intermediately on a seven-point Likert scale item scale were $6.01,4.83,4.62$ and 4.41, respectively. The median values for the variables I1, I5, I10 and I8 were found $5,5,5$ and 4 , respectively.

Section Ii-Iiii: Respondents were asked about the level of effect on a seven-point Likert item scale given towards the company's future plans and development due to three different type of reliability issues mentioned below i.e. planned outages (Ii), load shedding (Iii) and unplanned outages (Iiii) for all the variables, separately, from I1 to I10.

\begin{tabular}{c|c|c|c|c|cc|c}
\hline 1 & 2 & 3 & 5 & 6 & 7 \\
\hline $\begin{array}{c}\text { Not at all } \\
\text { effected }\end{array}$ & $\begin{array}{c}\text { Slightly } \\
\text { effected }\end{array}$ & $\begin{array}{c}\text { Somewhat } \\
\text { effected }\end{array}$ & $\begin{array}{c}\text { Moderately } \\
\text { effected }\end{array}$ & $\begin{array}{c}\text { Considerably } \\
\text { effected }\end{array}$ & $\begin{array}{c}\text { Highly } \\
\text { effected }\end{array}$ & $\begin{array}{c}\text { Extremely } \\
\text { effected }\end{array}$ \\
\hline
\end{tabular}

Friedman Test- Null-Hypothesis: The distributions of the variables formed by considering the three types of reliability issues i.e. planned outages (Ii), load shedding (Iii) and unplanned outages (Iiii) for all the variables, separately, from I1 to I10 are the same. The same respondents were measured on a different variable, but using the same seven-point Likert item effect scale, Friedman test was found suitable to determine any difference between their effect levels.

\author{
I1. Diversification \\ I2. Growth or expansion of existing unit \\ I3. Moving industries to other state with good energy facil- \\ ities \\ I4. Outsourcing at high cost, change in policy (making to \\ buy) \\ I5. Supplier selection and material procurement plan
}

\author{
I6. Venturing new markets \\ I7. Procurement of bank loans \\ I8. Change in process design based on low energy require- \\ ment \\ I9. Like to go for costly alternative energy sources
}

I10. Enhancing the reserve and inventory level

Table 7 and Table 8 given here are portraying the Friedman test statistics and descriptive statistics for the variables I1 to I10 measured at three levels of power system reliability issues i.e. planned outages, load shedding and unplanned outages. Actually, the effects of these three levels of reliability issues were obtained on each variable from I1 to I10, showing the companies' future plans and decisions or strategies using a level of effect scale - a seven-point Likert item scale. A Friedman test was run to determine whether or not there were differences in level of effect scores among three levels of power system reliability issues i.e. planned outages, load shedding and unplanned outages. Pairwise comparisons were performed with a Bonferroni correction for multiple comparisons. Level of effect score was statistically significantly different among three levels of reliability issues, which is evident from the Friedman Q or 
$\chi 2(2)$ test statistics and $p$ values for the each variable formed by considering the companies' future plans (I1 to I10) at three levels of reliability issues.

\section{Table 7}

Friedman Q statistics- Level of effect by different reliability issues on future plans and strategies

\begin{tabular}{|c|c|c|c|c|c|c|c|c|c|}
\hline \multirow[b]{2}{*}{$\begin{array}{l}\text { Dependent } \\
\text { Variables }\end{array}$} & \multirow[b]{2}{*}{$\begin{array}{c}\text { Type of Outages/ Relia- } \\
\text { bility Issues }\end{array}$} & \multirow[b]{2}{*}{ Median } & \multirow{2}{*}{$\begin{array}{c}\text { F-Q } \\
\text { Mean } \\
\text { Rank }\end{array}$} & \multicolumn{6}{|c|}{ Bonferroni Dunn's Post Hoc } \\
\hline & & & & $\begin{array}{l}\text { Group } \\
\text { Pairs }\end{array}$ & $\begin{array}{l}\text { Test Sta- } \\
\text { tistics }\end{array}$ & $\begin{array}{l}\text { Standard } \\
\text { Error }\end{array}$ & $\begin{array}{l}\text { Test Std. } \\
\text { Statistics }\end{array}$ & $\begin{array}{c}\mathrm{p}- \\
\text { value }\end{array}$ & $\begin{array}{l}\text { Adj. p- } \\
\text { value }\end{array}$ \\
\hline \multirow{4}{*}{ I1 } & 1- I1i Planned & 3.00 & 1.02 & $1-2$ & -1.128 & 0.116 & -9.707 & 0.000 & 0.000 \\
\hline & 2- I1ii Load Shedding & 5.00 & 2.15 & $2-3$ & -0.693 & 0.116 & -5.958 & 0.000 & 0.000 \\
\hline & 3- I1iii Unplanned & 6.00 & 2.84 & $3-1$ & -1.821 & 0.116 & -15.664 & 0.000 & 0.000 \\
\hline & \multicolumn{3}{|c|}{$|\mathrm{p}=0.000| \mathrm{Q}=271.622, \mathrm{df}=2 \mid$} & \multicolumn{6}{|c|}{ | Kendall's Coefficient of Concordance Stat., W=0.918 | } \\
\hline \multirow{4}{*}{$\mathbf{I} 2$} & 1- I2i Planned & 4.00 & 1.16 & $1-2$ & -0.770 & 0.116 & -6.626 & 0.000 & 0.000 \\
\hline & 2- I2ii Load Shedding & 5.00 & 1.93 & $2-3$ & -0.983 & 0.116 & -8.457 & 0.000 & 0.000 \\
\hline & 3- I2iii Unplanned & 6.00 & 2.91 & $3-1$ & -1.753 & 0.116 & -15.083 & 0.000 & 0.000 \\
\hline & \multicolumn{3}{|c|}{$|\mathrm{p}=0.000| \mathrm{Q}=253.925, \mathrm{df}=2 \mid$} & \multicolumn{6}{|c|}{ Kendall's Coefficient of Concordance Stat., W=0.858 | } \\
\hline \multirow{4}{*}{ I3 } & 1- I3i Planned & 4.00 & 1.09 & $1-2$ & -0.963 & 0.116 & -8.283 & 0.000 & 0.000 \\
\hline & 2- I3ii Load Shedding & 5.00 & 2.06 & $2-3$ & -0.791 & 0.116 & -6.800 & 0.000 & 0.000 \\
\hline & 3- I3iii Unplanned & 6.00 & 2.85 & $3-1$ & -1.753 & 0.116 & -15.083 & 0.000 & 0.000 \\
\hline & \multicolumn{3}{|c|}{$|\mathrm{p}=0.000| \mathrm{Q}=254.452, \mathrm{df}=2 \mid$} & \multicolumn{6}{|c|}{$\mid$ Kendall's Coefficient of Concordance Stat., $W=0.860 \mid$} \\
\hline \multirow{4}{*}{ I4 } & 1- I4i Planned & 2.00 & 1.20 & $1-2$ & -0.831 & 0.116 & -7.149 & 0.000 & 0.000 \\
\hline & 2- I4ii Load Shedding & 3.00 & 2.03 & $2-3$ & -1.571 & 0.116 & -13.514 & 0.000 & 0.000 \\
\hline & 3- I4iii Unplanned & 4.00 & 2.77 & $3-1$ & -0.740 & 0.116 & -6.365 & 0.000 & 0.000 \\
\hline & \multicolumn{3}{|c|}{$|\mathrm{p}=0.000| \mathrm{Q}=224.552, \mathrm{df}=2 \mid$} & \multicolumn{6}{|c|}{$\mid$ Kendall's Coefficient of Concordance Stat., $W=0.759 \mid$} \\
\hline \multirow{4}{*}{ I5 } & 1- I5i Planned & 4.00 & 1.41 & $1-2$ & -0.230 & 0.116 & -1.976 & 0.048 & 0.144 \\
\hline & 2- I5ii Load Shedding & 4.00 & 1.64 & $2-3$ & -1.324 & 0.116 & -11.392 & 0.000 & 0.000 \\
\hline & 3- I5iii Unplanned & 6.00 & 2.96 & $3-1$ & -1.554 & 0.116 & -13.368 & 0.000 & 0.000 \\
\hline & \multicolumn{3}{|c|}{$|\mathrm{p}=0.000| \mathrm{Q}=239.875, \mathrm{df}=2 \mid$} & \multicolumn{6}{|c|}{$\mid$ Kendall's Coefficient of Concordance Stat., $W=0.810 \mid$} \\
\hline \multirow{4}{*}{ I6 } & 1- I6i Planned & 3.00 & 1.49 & $1-2$ & -0.419 & 0.116 & -3.604 & 0.000 & 0.001 \\
\hline & 2- I6ii Load Shedding & 3.00 & 1.91 & $2-3$ & -0.693 & 0.116 & -5.958 & 0.000 & 0.000 \\
\hline & 3- I6iii Unplanned & 4.00 & 2.60 & $3-1$ & -1.111 & 0.116 & -9.561 & 0.000 & 0.000 \\
\hline & \multicolumn{3}{|c|}{$|\mathrm{p}=0.000| \mathrm{Q}=149.227, \mathrm{df}=2 \mid$} & \multicolumn{6}{|c|}{ | Kendall's Coefficient of Concordance Stat., $W=0.504 \mid$} \\
\hline & 1- I7i Planned & 3.00 & 1.37 & $1-2$ & -0.524 & 0.116 & -4.505 & 0.000 & 0.000 \\
\hline & 2- I7ii Load Shedding & 3.00 & 1.90 & $2-3$ & -0.838 & 0.116 & -7.207 & 0.000 & 0.000 \\
\hline 17 & 3- I7iii Unplanned & 4.00 & 2.73 & $3-1$ & -1.361 & 0.116 & -11.712 & 0.000 & 0.000 \\
\hline & $|\mathrm{p}=0.000| \mathrm{Q}=187$ & $406, \mathrm{df}=2$ & & Ken & all's Coeff & ient of $\mathrm{Co}$ & cordance S & at., $\mathrm{W}=$ & 0.633 \\
\hline & 1- I8i Planned & 2.00 & 1.35 & $1-2$ & -0.753 & 0.116 & -6.481 & 0.000 & 0.000 \\
\hline I8 & 2- I8ii Load Shedding & 3.00 & 2.10 & $2-3$ & -0.449 & 0.116 & -3.865 & 0.000 & 0.000 \\
\hline 18 & 3- I8iii Unplanned & 3.00 & 2.55 & $3-1$ & -1.203 & 0.116 & -10.346 & 0.000 & 0.000 \\
\hline & \begin{tabular}{l|l|l} 
& $p=0.000 \mid Q=157$
\end{tabular} & $083, \mathrm{df}=2$ & & Ken & all's Coeff & ient of $\mathrm{Co}$ & cordance S & at., $\mathrm{W}=$ & 0.531 \\
\hline & 1- I9i Planned & 4.00 & 1.05 & $1-2$ & -1.720 & 0.116 & -14.793 & 0.000 & 0.000 \\
\hline & 2- I9ii Load Shedding & 6.00 & 2.77 & $2-3$ & 0.601 & 0.116 & 5.173 & 0.000 & 0.000 \\
\hline 19 & 3- I9iii Unplanned & 5.00 & 2.17 & $3-1$ & -1.118 & 0.116 & -9.619 & 0.000 & 0.000 \\
\hline & $|\mathrm{p}=0.000| \mathrm{Q}=260$ & $121, \mathrm{df}=2$ & & & all's Coeff & ient of $\mathrm{Cc}$ & cordance $S$ & at., $\mathrm{W}=$ & 0.879 \\
\hline & 1- I10i Planned & 3.00 & 1.10 & $1-2$ & -0.970 & 0.116 & -8.341 & 0.000 & 0.000 \\
\hline & 2- I10ii Load Shedding & 4.00 & 2.07 & $2-3$ & -0.747 & 0.116 & -6.423 & 0.000 & 0.000 \\
\hline 110 & 3- I10iii Unplanned & 5.00 & 2.82 & $3-1$ & -1.716 & 0.116 & -14.763 & 0.000 & 0.000 \\
\hline & $|\mathrm{p}=0.000| \mathrm{Q}=250$ & $983, \mathrm{df}=2$ & & $\mathrm{Ke}$ & lll's Coef & ent of $\mathrm{Cc}$ & cordance & at., $\mathrm{W}=$ & 0.848 \\
\hline
\end{tabular}

The Bonferroni Dunn's post hoc analysis revealed statistically significant differences in level of effect score from planned outages (Ii) load shedding (Iii); load shedding (Iii) unplanned outages (Iiii) planned outages (Ii) and unplanned outages (Iiii) except only one insignificant pair under I5 between planned outages (I5) - load shedding (I5ii). A higher mean rank portrays that the variable is scored high on survey scale and the effect of that specific reliability issue is higher on the companies' future plans. Almost all the companies' future plans and decisions (I1 to I10) were found badly impacted by the unplanned outages followed by the load shedding and the planned outages as evident from the mean ranks shown in the Table 7. A Kendall's W statistics was used to reveal the level of agreement among the respondents 
for each variable formed by the three levels of reliability issues. Except for the variables I6, I7 and I8 with Kendall's W value of 0.504, 0.633 and 0.531 , respectively, all the other variables had Kendall's W value more than 0.70 which indicated fairly good level of agreement among the survey raters.

\section{Table 8}

Descriptive statistics- Level of effect by different reliability issues on future plans and strategies

\begin{tabular}{|c|c|c|c|c|c|c|c|c|c|c|c|c|c|}
\hline \multirow{3}{*}{$\begin{array}{l}\text { Dependent } \\
\text { Variables }\end{array}$} & \multirow{3}{*}{$\begin{array}{l}\text { Type of Outages/ } \\
\text { Reliability Issues }\end{array}$} & \multirow{2}{*}{\multicolumn{3}{|c|}{ Percentiles }} & \multirow{3}{*}{ Mean } & \multirow{3}{*}{$\begin{array}{l}\text { Std. } \\
\text { Dev. }\end{array}$} & \multirow{3}{*}{ 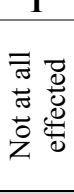 } & 2 & 3 & 4 & 5 & 6 & 7 \\
\hline & & & & & & & & \multirow{2}{*}{ 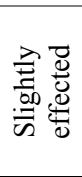 } & \multirow{2}{*}{ 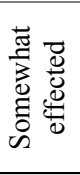 } & \multirow{2}{*}{ 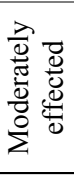 } & \multirow{2}{*}{ 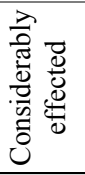 } & \multirow{2}{*}{ 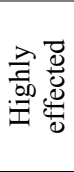 } & \multirow{2}{*}{ 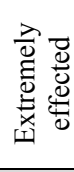 } \\
\hline & & 5 th & $\begin{array}{c}\text { 50th } \\
\text { (Median) }\end{array}$ & 75th & & & & & & & & & \\
\hline \multirow{3}{*}{ I1 } & 1- Ili Planned & 3.00 & 3.00 & 4.00 & 3.49 & 0.589 & $0 \%$ & $3 \%$ & $48 \%$ & $47 \%$ & $2 \%$ & $0 \%$ & $0 \%$ \\
\hline & 2- I1ii Load Sheddir & & 5.00 & & & 0.581 & $0 \%$ & $0 \%$ & $0 \%$ & $8 \%$ & $61 \%$ & $30 \%$ & $0 \%$ \\
\hline & 3- I1iii Unplanned & .00 & 6.00 & 6.00 & 6.03 & 0.368 & $0 \%$ & $0 \%$ & $0 \%$ & $0 \%$ & $5 \%$ & $86 \%$ & $8 \%$ \\
\hline \multirow{3}{*}{ I2 } & 1- I2i Planned & .00 & 4.00 & 5.00 & 4.27 & 0.516 & $0 \%$ & $0 \%$ & $3 \%$ & $66 \%$ & $30 \%$ & $0 \%$ & $0 \%$ \\
\hline & 2- I2ii Load Shedding & & 5.00 & & 5.11 & 0.536 & $0 \%$ & $0 \%$ & $0 \%$ & $9 \%$ & $70 \%$ & $20 \%$ & $0 \%$ \\
\hline & 3- I2iii Unplanned & 00 & 6.00 & 6.00 & 6.22 & 0.460 & $0 \%$ & $0 \%$ & $0 \%$ & $0 \%$ & $2 \%$ & $74 \%$ & $24 \%$ \\
\hline \multirow{3}{*}{ I3 } & 1- I3i Planned & 3.00 & 4.00 & 4.00 & 3.74 & 0.523 & $0 \%$ & $0 \%$ & $30 \%$ & $66 \%$ & $4 \%$ & $0 \%$ & $0 \%$ \\
\hline & 2- I3ii Load Shed & 5.00 & 5.00 & 5.00 & 4.93 & 0.618 & $0 \%$ & $0 \%$ & $0 \%$ & $23 \%$ & $61 \%$ & $16 \%$ & $0 \%$ \\
\hline & 3- I3iii Unplanne & 00 & 6.00 & 6.00 & 5.93 & 0.482 & $0 \%$ & $0 \%$ & $0 \%$ & $0 \%$ & $16 \%$ & $76 \%$ & $8 \%$ \\
\hline \multirow{3}{*}{ I4 } & 1- I4i Planned & 2.00 & 2.00 & 2.00 & 2.20 & 0.436 & $1 \%$ & $77 \%$ & $22 \%$ & $0 \%$ & $0 \%$ & $0 \%$ & $0 \%$ \\
\hline & 2- I4ii Load She & 3.00 & 3.00 & 3.00 & 2.99 & 0.466 & $0 \%$ & $11 \%$ & $78 \%$ & $10 \%$ & $0 \%$ & $0 \%$ & $0 \%$ \\
\hline & 3- I4iii Unplanned & 3.00 & 4.00 & 4.00 & 3.73 & 0.567 & $0 \%$ & $0 \%$ & $33 \%$ & $61 \%$ & $6 \%$ & $0 \%$ & $0 \%$ \\
\hline \multirow{3}{*}{ I5 } & 1- I5i Planned & 4.00 & 4.00 & 4.00 & 3.94 & 0.620 & $0 \%$ & $0 \%$ & $22 \%$ & $61 \%$ & $16 \%$ & $0 \%$ & $0 \%$ \\
\hline & 2- I5ii Load She & 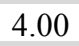 & 4.00 & 5.00 & 4.20 & 0.521 & $0 \%$ & $0 \%$ & $5 \%$ & $69 \%$ & $26 \%$ & $0 \%$ & $0 \%$ \\
\hline & 3- I5iii Unplanned & & & & & & $0 \%$ & $0 \%$ & $0 \%$ & $0 \%$ & $20 \%$ & $72 \%$ & $7 \%$ \\
\hline \multirow{3}{*}{ I6 } & 1- H6i Planned & & 3.00 & 3.00 & 2.80 & 0.403 & $0 \%$ & $20 \%$ & $80 \%$ & $0 \%$ & $0 \%$ & $0 \%$ & $0 \%$ \\
\hline & 2- H6ii Load She & 200 & 3.00 & 3.00 & & 0.471 & $0 \%$ & $5 \%$ & $76 \%$ & $18 \%$ & $0 \%$ & $0 \%$ & $0 \%$ \\
\hline & 3- H6iii U & & & & & & $0 \%$ & $0 \%$ & $36 \%$ & $61 \%$ & $3 \%$ & $0 \%$ & $0 \%$ \\
\hline \multirow{3}{*}{ I7 } & 1- I7i Planned & 3.00 & 3.00 & 3.00 & 2.99 & 0.369 & $0 \%$ & $7 \%$ & $86 \%$ & $6 \%$ & $0 \%$ & $0 \%$ & $0 \%$ \\
\hline & 2- I7ii Load Shec & 3.00 & 3.00 & 4.00 & 3.39 & 0.541 & $0 \%$ & $3 \%$ & $56 \%$ & $41 \%$ & $0 \%$ & $0 \%$ & $0 \%$ \\
\hline & 3- I7iii Unplanned & & 4.00 & 5.00 & 4.18 & 0.595 & $0 \%$ & $0 \%$ & $10 \%$ & $61 \%$ & $28 \%$ & $0 \%$ & $0 \%$ \\
\hline \multirow{3}{*}{ I8 } & 1- I8i Planned & 2.00 & 2.00 & 3.00 & 2.39 & 0.488 & $0 \%$ & $61 \%$ & $39 \%$ & $0 \%$ & $0 \%$ & $0 \%$ & $0 \%$ \\
\hline & 2- I8ii Load She & 3.00 & 3.00 & 3.00 & 2.95 & 0.426 & $0 \%$ & $11 \%$ & $82 \%$ & $7 \%$ & $0 \%$ & $0 \%$ & $0 \%$ \\
\hline & 3- I8iii Unplanned & 3.00 & 3.00 & 4.00 & 3.33 & 0.539 & $0 \%$ & $3 \%$ & $60 \%$ & $36 \%$ & $0 \%$ & $0 \%$ & $0 \%$ \\
\hline \multirow{3}{*}{ I9 } & 1- I9i Planned & 4.00 & 4.00 & 4.00 & 3.96 & 0.582 & $0 \%$ & $0 \%$ & $19 \%$ & $66 \%$ & $15 \%$ & $0 \%$ & $0 \%$ \\
\hline & 2- I9ii Load Shed & 6.00 & 6.00 & 6.00 & 6.16 & 0.437 & $0 \%$ & $0 \%$ & $0 \%$ & $0 \%$ & $3 \%$ & $78 \%$ & $19 \%$ \\
\hline & 3- I9iii Unplanned & 5.00 & 5.00 & 6.00 & 5.47 & 0.527 & $0 \%$ & $0 \%$ & $0 \%$ & $1 \%$ & $53 \%$ & $46 \%$ & $1 \%$ \\
\hline \multirow{3}{*}{ I10 } & 1- I10i Planned & 3.00 & 3.00 & 4.00 & 3.27 & 0.503 & $0 \%$ & $3 \%$ & $68 \%$ & $30 \%$ & $0 \%$ & $0 \%$ & $0 \%$ \\
\hline & 2- I10ii Load Shedding & 4.00 & 4.00 & 5.00 & 4.45 & 0.587 & $0 \%$ & $0 \%$ & $3 \%$ & $52 \%$ & $43 \%$ & $2 \%$ & $0 \%$ \\
\hline & 3- I10iii Unplanned & 5.00 & 5.00 & 6.00 & 5.35 & 0.545 & $0 \%$ & $0 \%$ & $0 \%$ & $3 \%$ & $60 \%$ & $36 \%$ & $1 \%$ \\
\hline
\end{tabular}

Section L: Respondents were asked about the level of preference on a seven-point Likert item scale given towards the outage mitigation methods mentioned below from L1 to L6.

\begin{tabular}{cc|ccc|cc}
\hline 1 & 2 & 3 & 4 & 5 & 7 \\
\hline $\begin{array}{l}\text { Not at all } \\
\text { preferred }\end{array}$ & $\begin{array}{c}\text { Slightly } \\
\text { preferred }\end{array}$ & $\begin{array}{c}\text { Somewhat } \\
\text { preferred }\end{array}$ & $\begin{array}{c}\text { Moderately } \\
\text { preferred }\end{array}$ & $\begin{array}{c}\text { Considerably } \\
\text { preferred }\end{array}$ & $\begin{array}{c}\text { Highly } \\
\text { preferred }\end{array}$ & $\begin{array}{c}\text { Extremely } \\
\text { preferred }\end{array}$ \\
\hline
\end{tabular}

Friedman Test- Null-Hypothesis: The distributions of the variables from L1 to L6 are the same. As the same respondents were measured on a different variable, but using the same seven-point Likert item preference scale, Friedman test was found suitable to determine any difference between their preference levels.

L1. Improved system protection

L2. Improved local protection (at your firm)

L3. Building local (at your firm) backup generation
L4. Building solar power backup generation

L5. Building biogas power backup generation

L6. Building cogeneration power backup generation 
Table 9

Friedman Q and descriptive statistics- Level of preference towards the outage mitigation methods

\begin{tabular}{|c|c|c|c|c|c|c|c|c|c|c|c|c|c|}
\hline \multicolumn{7}{|c|}{ | Test Statistics- Friedman's Q | Chi-Square= 576.478 | } & \multicolumn{7}{|c|}{ | Kendal's W= 0.779} \\
\hline \multirow{4}{*}{$\begin{array}{c}\text { Dependent } \\
\text { Variables }\end{array}$} & Asym & Sig. & $0-$ Value $)=0$ & $000 \mid$ & & & & $\mathrm{N}=1$ & $48, \mathrm{De}$ & gree 0 & Freedc & $n=05$ & \\
\hline & \multirow{3}{*}{$\begin{array}{l}\text { Mean } \\
\text { Rank }\end{array}$} & & & & \multirow{3}{*}{ Mean } & \multirow{3}{*}{$\begin{array}{l}\text { Std. } \\
\text { Dev. }\end{array}$} & 1 & 2 & 3 & 4 & 5 & 6 & 7 \\
\hline & & \multicolumn{3}{|c|}{ Percentiles } & & & \multirow{2}{*}{ 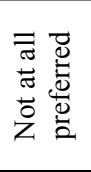 } & \multirow{2}{*}{ 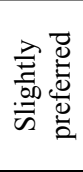 } & \multirow{2}{*}{ 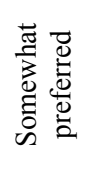 } & \multirow{2}{*}{ 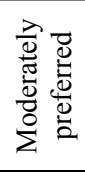 } & \multirow{2}{*}{ 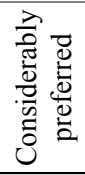 } & \multirow{2}{*}{ 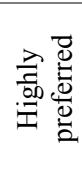 } & \multirow{2}{*}{ 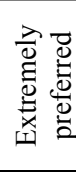 } \\
\hline & & 25 th & $\begin{array}{c}\text { 50th } \\
\text { (Median) }\end{array}$ & 75 th & & & & & & & & & \\
\hline $\mathbf{L 1}$ & 5.48 & 6.00 & 6.00 & 7.0 & 6.30 & 0.4 & $0 \%$ & $0 \%$ & $0 \%$ & $0 \%$ & $1 \%$ & $67 \%$ & $32 \%$ \\
\hline L2 & 4.75 & 6.00 & 6.00 & 6.00 & 5.84 & 0.416 & $0 \%$ & $0 \%$ & $0 \%$ & $0 \%$ & $18 \%$ & $80 \%$ & $2 \%$ \\
\hline L4 & 3.99 & 5.00 & 5.00 & 6.00 & 5.47 & 0.501 & $0 \%$ & $0 \%$ & $0 \%$ & $0 \%$ & $53 \%$ & $47 \%$ & $0 \%$ \\
\hline L5 & 3.11 & 5.00 & 5.00 & 5.00 & 5.03 & 0.501 & $0 \%$ & $0 \%$ & $0 \%$ & $11 \%$ & $75 \%$ & $14 \%$ & $0 \%$ \\
\hline L6 & 2.23 & 4.00 & 5.00 & 5.00 & 4.57 & 0.524 & $0 \%$ & $0 \%$ & $1 \%$ & $43 \%$ & $56 \%$ & $1 \%$ & $0 \%$ \\
\hline L3 & 1.44 & 4.00 & 4.00 & 4.00 & 4.10 & 0.416 & $0 \%$ & $0 \%$ & $4 \%$ & $82 \%$ & $14 \%$ & $0 \%$ & $0 \%$ \\
\hline
\end{tabular}

Table 10

Bonferroni Dunn's post hoc- Level of preference towards the outage mitigation methods

\begin{tabular}{|c|c|c|c|c|c|c|c|c|c|c|c|}
\hline $\begin{array}{l}\text { Sample1- } \\
\text { Sample2 }\end{array}$ & $\begin{array}{c}\text { Test } \\
\text { Statistic }\end{array}$ & $\begin{array}{l}\text { Std. } \\
\text { Error }\end{array}$ & $\begin{array}{l}\text { Std. Test } \\
\text { Statistic }\end{array}$ & Sig. & $\begin{array}{l}\text { Adj. } \\
\text { Sig. }\end{array}$ & $\begin{array}{l}\text { Sample1- } \\
\text { Sample2 }\end{array}$ & $\begin{array}{c}\text { Test } \\
\text { Statistic }\end{array}$ & $\begin{array}{c}\text { Std. } \\
\text { Error }\end{array}$ & $\begin{array}{l}\text { Std. Test } \\
\text { Statistic }\end{array}$ & Sig. & $\begin{array}{l}\text { Adj. } \\
\text { Sig. }\end{array}$ \\
\hline L3-L6 & -0.794 & 0.217 & -3.651 & 0.000 & 0.004 & L6-L1 & 3.247 & 0.217 & 14.928 & 0.000 & 0.000 \\
\hline L3-L5 & -1.669 & 0.217 & -7.674 & 0.000 & 0.000 & L5-L4 & 0.885 & 0.217 & 4.070 & 0.000 & 0.001 \\
\hline L3-L4 & -2.554 & 0.217 & -11.744 & 0.000 & 0.000 & L5-L2 & 1.639 & 0.217 & 7.534 & 0.000 & 0.000 \\
\hline L3-L2 & 3.307 & 0.217 & 15.208 & 0.000 & 0.000 & L5-L1 & 2.372 & 0.217 & 10.905 & 0.000 & 0.000 \\
\hline L3-L1 & 4.041 & 0.217 & 18.579 & 0.000 & 0.000 & L4-L2 & 0.753 & 0.217 & 3.464 & 0.001 & 0.008 \\
\hline L6-L5 & 0.875 & 0.217 & 4.023 & 0.000 & 0.001 & L4-L1 & 1.486 & 0.217 & 6.835 & 0.000 & 0.000 \\
\hline L6-L4 & 1.760 & 0.217 & 8.093 & 0.000 & 0.000 & L2-L1 & 0.733 & 0.217 & 3.371 & 0.001 & 0.011 \\
\hline L6-L2 & 2.514 & 0.217 & 11.557 & 0.000 & 0.000 & & & & & & \\
\hline
\end{tabular}

Each row tests the null hypothesis that the Sample 1 and Sample 2 distributions are the same.

Asymptotic significances (2-sided tests) are displayed. The significance level is .05.

a. Significance values have been adjusted by the Bonferroni correction for multiple tests.

Table 9 and Table 10 show the Friedman statistics along with the key descriptive statistics, and Bonferroni Dunn's post hoc statistics for the variables from L1 to L6, depicting the outage mitigation methods, respectively. The variables shown in Table 9 are arranged in the descending order of their mean ranks attained by applying the Friedman test in SPSS 24. A Friedman test was run to determine whether or not there were differences in preference scores among the different variables from L1 to L6. Pairwise comparisons were made with a Bonferroni correction for multiple comparisons. Level of preference score was statistically significantly different among the different variables, Friedman's Q or $\chi 2(5)=576.478$, $p=0.000$. The Bonferroni Dunn's post hoc analysis exposed statistically significant differences among the level of preference scores for all the possible pairwise combinations formed by the dependent variables except for the pairs L3-L6, L4-L2 and L2-L1 as shown in the Table 10. The significance level used here is 0.003 , obtained by the original p-value of 0.05 divided by the number of possible pairwise combinations which are ten (15) for the present scenario. None of the pairwise comparison showed insignificant result as all the p-values were found below 0.003 . The adjusted p-values in the last column revealed that none of the value fall below a significance level of 0.05 and hence showing the significant results. The higher mean ranks of 5.48 and 4.75 , for the variables, improved system protection (L1) and improved local protection- at your firm (L2), portrayed that the respondents highly preferred the improvement of the power system and local protection as compared other outage mitigation methods. Further, the mean ranks of 2.23 and 1.44 were obtained for the variables building cogeneration power backup generation (L6) and building local (at your firm) backup generation (L3), which presented that these variables were scored markedly low on a seven-point survey scale of level of preference, representing that preference for these outage mitigation methods was quite low as compared to other mitigation methods to reduce the impact of power outages. The median values for the variables L1, L2, L3, L4, L5 and L6 were 6, 6, $5,5,5$ and 4, respectively. A considerably good level of agreement was found as shown by the Kendal's 
W value of 0.779 , among the survey raters. A Tableau 2018.1 software was used to visualize the data of the categorical seven-point Likert item scale for all the sections which is clearly shown in the Fig. 2.

\begin{tabular}{|c|c|c|c|c|c|}
\hline \multicolumn{4}{|c|}{ B1 System voltage fluctuations } & & \\
\hline \multicolumn{6}{|c|}{ System frequency fluctuations } \\
\hline B3 & \multicolumn{5}{|l|}{ System transient faults } \\
\hline B4 & \multicolumn{5}{|c|}{ System switching/operating errors } \\
\hline B5 & \multicolumn{5}{|c|}{ System protection/relaying problems } \\
\hline B6 & \multicolumn{5}{|c|}{ System transmission overloading } \\
\hline B7 & \multicolumn{5}{|l|}{ System supply deficit } \\
\hline B8 & \multicolumn{5}{|c|}{ Unplanned power outages } \\
\hline B9 & \multicolumn{5}{|l|}{ Planned power outages } \\
\hline 01 & \multicolumn{5}{|c|}{ Unplanned power outages-1 hour scenario } \\
\hline 02 & \multicolumn{5}{|c|}{ Dangerous advance warning planned power outages -1 hour scenario } \\
\hline 03 & \multicolumn{5}{|c|}{ Safe advance warning planned power outages- 1 hour scenario } \\
\hline 04 & \multicolumn{5}{|c|}{ Long length load shedding (Weekly off days)-1 hour scenario } \\
\hline 05 & \multicolumn{5}{|c|}{ Short length load shedding (Peak load days)-1 hour scenario } \\
\hline 11 & \multicolumn{5}{|l|}{ Diversification } \\
\hline 12 & \multicolumn{5}{|c|}{ Growth or expansion of existing unit } \\
\hline 13 & \multicolumn{5}{|c|}{ Moving industries to other state with good energy facilities } \\
\hline 14 & \multicolumn{5}{|c|}{ Outsourcing at high cost, change in policy (making to buy) } \\
\hline 15 & \multicolumn{5}{|c|}{ Supplier selection and material procurement plan } \\
\hline 16 & \multicolumn{5}{|l|}{ Venturing new markets } \\
\hline 17 & \multicolumn{5}{|c|}{ Procurement of bank loans } \\
\hline 18 & \multicolumn{5}{|c|}{ Change in process design based on low energy requirement } \\
\hline 19 & \multicolumn{5}{|c|}{ Like to go for costly alternative energy sources } \\
\hline I10 & \multicolumn{5}{|c|}{ Enhancing the reserve and inventory level } \\
\hline L1 & \multicolumn{5}{|c|}{ Improved system protection } \\
\hline L2 & \multicolumn{5}{|c|}{ Improved local protection (at your firm) } \\
\hline L3 & \multicolumn{5}{|c|}{ Building local (at your firm) backup generation } \\
\hline L4 & \multicolumn{5}{|c|}{ Building solar power backup generation } \\
\hline L5 & Building biogas power $b$ & p generation & & & \\
\hline L6 & Building cogeneration & r backup generation & & & \\
\hline 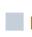 & Not at all concerned & & & & \\
\hline - & Slightly concerned & & Sli & lightly important & \\
\hline 口 & Somewhat concerned & Somewhat disruptive & So & iomewhat important & Somewhat preferred \\
\hline$\square$ & Moderately concerned & Moderately disruptive & Mo & loderately important & Moderately preferred \\
\hline & Considerably concerned & Considerably disruptive & & onsiderably important & Considerably preferred \\
\hline 口 & Highly concerned & Highly disruptive & & lighly important & Highly preferred \\
\hline 口 & Extremely concerned & Completely disruptive & & xtremely important & Extremely preferred \\
\hline
\end{tabular}

Fig. 2. Data visualization of the categorical seven-point Likert item scale for all the sections considered

\section{Conclusions}

The statistical analysis of the different variables under separate sections were performed. The section-B revealed that the power system reliability issues were the major concern as per the responses of the textile industries as compared to the power system quality issues. The results of this section exposed that the power systems of the utility company connected to the industries under study were not reliable. Moreover, the micro scale industries were found more oriented towards the reliability problems as compared with the small scale textile industries. While seeing the results of Section-O, it was found that the one hour unplanned outage followed by the one hour dangerous advance warning, planned power outage were more disruptive than the other type of one outage scenarios. Further, the Section-I revealed that, growth or expansion of existing unit, like to go for costly alternative energy sources, procurement of bank loans and moving industries to other state with good energy facilities, were the four most important future plans and decisions which can be highly effected due to the occurrence of different types of reliability problems. Referring to the statistics of the Section I considering the three categories of the reliability issues i.e. Ii-Iii-Iiii, almost all the future plans and strategies were found dominantly effected by the 
unplanned outages followed by the load shedding and the planned outages as per the opinion of the textile industries. The results of the different sections of the survey revealed that the reliability issues were significantly effecting the future plans and strategies of the textile industries.

\section{Acknowledgments}

Author is extremely thankful to I.K Gujral, Punjab Technical University, Kapurthala (Punjab), India, for providing him the opportunity to accomplish this research work. Author would like to specially thank research supervisor, Dr Harpuneet Singh, Assistant Professor, Department of Production Engineering), Guru Nanak Dev Engineering College, Ludhiana (Punjab), India who encouraged and directed me to complete the research work. As well, the author expresses his sincerest thanks to textile industries in Punjab for sparing their precious time for filling the questionnaire schedules through the interview sessions.

\section{References}

Adenikinju, A. F. (2005, January). Analysis of the cost of infrastructure failures in a developing economy: The Case of The Electricity Sector in Nigeria. AERC Research Paper, 148, 1-38.

Akinbola, O., Zekeri, A., \& Idowu, H. (2017). The power sector and its impacts on industrialization of businesses in Nigeria. Archives of Business Research, 5(12), 294-305. doi:10.14738/abr.512.4018

Baarsma, B. E., \& Hop, J. P. (2009, June). Pricing power outages in the Netherland. Energy, 34, 1378-1386.

Bhargava, C., Imran, M., \& Murty, P. (2012, July). Reliability cost assessment for upgrading feeder by using customer surveys. International Journal of Innovative Technology and Exploring Engineering, 1(2), 172-178.

Carlsson, F., Demeke, E., Martinsson, P., \& Tesemma, T. (2018). Cost of Power Outages for Manufacturing Firms in Ethiopia: A Stated Preference Study. Working Paper in Economics No. 731. Sweden: Department of Economics, School of Business, Economics and Law, University of Gothenburg, Sweden.

Hayes, A. F. (2007). Answering the call for a standard reliability measure for coding data. Communication Methods and Measures, 1, 77-89.

Kivikko, K., Järventausta, P., \& Mäkinen, A. (2007). Research and analysis method comparison in finnish reliability worth study. C I R E D 19th International Conference on Electricity Distribution- 21-24 May 2007, (pp. 1-4). Vienna.

Krippendorff, K. (2011). Agreement and information in the reliability of coding. Communication Methods and Measures, 5(2), 93-112. doi:https://doi.org/10.1080/19312458.2011.568376

Lawton, L., Sullivan, M., Liere, K. V., Katz, A., \& Eto, J. (2003). A Framework and Review of Customer Outage Costs: Integration and Analysis of Electric Utility Outage Cost Surveys. Berkeley, CA: Ernest Orlando Lawrence Berkeley National Laboratory.

Lenhard, W., \& Lenhard, A. (2016). Calculation of Effect Sizes. (Dettelbach (Germany): Psychometrica) doi:DOI: 10.13140/RG.2.1.3478.4245

Oppurtunities in Textiles in Punjab. (2018). Retrieved September 27, 2018, from Invest Punjab: http://www.investpunjab.gov.in/Static/Textiles

Oyeyemi, A. M., Akoko, A. A., \& Akungba. (2018). Disaggregate energy supply and industrial output in nigeria. International Journal of Economics, Business and Management Research, 2(2), 154-172.

SARI/Energy, S. A. (February 2003). Economic Impact of Poor Power Quality on Industry. United States Agency for International Development (USAID), Sri Lanka.

Schienbein, L. A., \& DeSteese, J. G. (2002). Distributed Energy Resources, Power Quality and Reliability Background. Pacific Northwest National Laboratory, Battelle. Springfield: National Technical Information Service, U.S. Department of Commerce.

Wijayatunga, P. D., \& Jayalath, M. (2004). Assessment of economic impact of electricity supply interruptions in the Sri Lanka industrial sector. Energy Conversion and Management, 45(2), 235-247.

Wijayatunga, P. D., \& Jayalath, M. (2008, September). Economic impact of electricity supply interruptions on the industrial sector of Bangladesh. Energy for Sustainable Management, 12(3), 5-12.

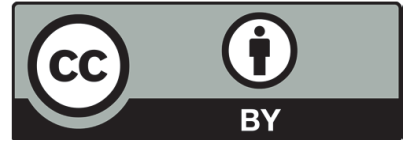

(C) 2019 by the authors; licensee Growing Science, Canada. This is an open access article distributed under the terms and conditions of the Creative Commons Attribution (CCBY) license (http://creativecommons.org/licenses/by/4.0/). 